\title{
On Transparency, Good Governance and the Fight against Corruption: Some Lessons (and Questions) from an International Law Perspective
}

\author{
Carmen PÉREZ GONZÁLEZ*
}

\begin{abstract}
'Anyone who has common sense will remember that the bewilderments of the eyes are of two kinds, and arise from two causes, either from coming out of the light or from going into the light' Plato, The Republic $(360 \mathrm{bc})$
\end{abstract}

'Sunlight is said to be the best of disinfectants; electric light the most efficient policeman'. Louis D. Brandeis, What Publicity Can Do (1913)

'Visibility is a trap' Michael Foucault, Discipline and Punish: The Birth of the Prison (1979)

\begin{abstract}
This article aims to shed some light on the role of transparency, good governance and the fight against corruption in contemporary International Law. While an increasing number of national and international initiatives seek to promote those goals in the public and private realms, by imposing obligations both on States, International Organizations, and private actors, the legal nature of these international obligations remain uncertain. This article first analyses the content and scope of the obligation of promoting transparency, good governance and fighting against corruption incorporated to different sectors of International Law. Secondly, it tries to contribute to the debate on the legal status of a global obligation of transparency that would be contained in a new rule of International Law. The legal nature of that rule, as well as their addresses and the legal consequences of its infringement will be considered. Final section contains concluding remarks.
\end{abstract}

Keywords: Transparency, good governance, corruption, access to information, international organizations, new standards in International Law.

\section{INTRODUCTION: CONCERNS OVER DEFINITIONS}

The aim of this work is to contribute to the debate on the role of transparency, good governance and the fight against corruption in contemporary International Law. It is not an easy task. Many important questions arise, and the issue can be examined from very different perspectives. Transparency, good governance, and the fight against corruption are celebrated concepts and objectives, nowadays. We are familiar with all of them. An increasing number of national and international initiatives seek to promote these goals in the public and private realms and enshrining them in law through incorporation into various legal instruments. These concepts and objectives can affect legal debates. A variety of international norms adopted in different sectors incorporate the obligation to fight corruption and/or promote good governance and transparency. A countless

* Lecturer in Public International Law, University Carlos III of Madrid. Email: carmen.perez@uczm.es. 
number of examples can be found. ${ }^{\mathrm{I}}$ But, at the same time, attempting to define these contextdependent concepts according to International Law is not without difficulties. Thus, the first obstacle is not a legal, but a terminological one. How do we define transparency, corruption and good governance?

Paradoxically, the concept of transparency is opaque. It is also an amorphous notion. ${ }^{2}$ There is a multitude of related concepts - publicity, publicness, openness - and antonyms - opacity, secrecy, confidentiality, complexity, disorder.$-{ }^{3}$ Transparency has been defined as a culture, ${ }^{4}$ a condition, a technique, ${ }^{5}$ an instrument, ${ }^{6}$ a structure that makes relevant information accessible. ${ }^{7}$ The benefits of transparency have been extensively glossed; it has been considered "the Swiss army knife of policy tools"; ${ }^{8}$ it has been said that transparency "serves as a foundational element of democratic participation and accountability" and "enables - and, indeed forces- [a] virtuous chain of events".? And, of course, transparency also has its detractors. ${ }^{10}$

Despite these (apparently minority) opinions, ${ }^{\text {II }}$ transparency is quasi universally recognized as a positive value. ${ }^{\mathrm{I} 2}$ In his essay "Perpetual Peace", Kant noted that publicity was a moral requirement for

r A recent study of different transparency issues in key areas of International Law can be found in: A. Bianchi and A. Peters, Transparency in International Law (Cambridge University Press, Cambridge, 2013).

2 G.I. Hernández, 'Turning Mirrors into Windows? Reflections on Transparency in International Law' 15, Journal of World Investment $\mathcal{O}$ Trade (2014) I087-II07 [DOI: 10.1163/22119000-01506017], at 1088.

A. Peters, 'Towards Transparency as a Global Norm', in Bianchi and Peters, supra n. I, at 534.

4 A. Bianchi, 'On Power and Illusion: The Concept of Transparency in International Law', in Bianchi and Peters, supra note I, at I.

5 According to Catà Backer, "(a)s technique, transparency is understood as the aggregate of methods of producing information for use in managing power relationships”: L. Catà Backer, Transparency Between Norm, Technique and Property in International Law and Governance-The Example of Corporate Disclosure Regimes and Environmental Impacts (20I2), available at < http://works.bepress.com/larry_backer/II> , accessed 2 October 2015.

6 A. Greppi, 'Contra la falsa transparencia: Genealogías y consecuencias en la esfera pública', 3 Teoría Política (2013) II5-I37, at I2I.

7 Peters, supra n. 3, at 534-535.

8 V. Haufler, 'Disclosure as governance: The extractive industries initiative and resource management in the developing world', io Global Environmental Politics (2010) 53-73 [DOI: I0.1162/GLEP_a_00oI4], at 55.

9 M. Fenster, 'Transparency in search of a theory', i8 European Journal of Social Theory (2015) I50-167 [DOI: IO.1177/13684310I4555257], at I5I.

ro "Transparency can mean populism triumphs over justice": N. Krisch and B. Kingsbury, 'Introduction: Global Governance and Global Administrative Law in the International Legal Order', 17 European Journal of International Law (2006) I-I3 [DOI: I0.I093/ejil/chir7o], at 4.

II Peters considers that “( $\mathrm{t}$ )ransparency must not be excessive. Too much transparency, the 'wrong kind' of transparency, transparency in the wrong moment, transparency with respect to certain contents or towards certain recipients may cause political and social problems both in terms of domestic and international law as well as regarding governance": Peters, supra n. 3, at 570 .

I2 At European Union (EU) level, the lack of transparency in the negotiations on the Transatlantic Trade and Investment Partnership (TTIP) has been perceived as a legitimacy deficit. Concerns have been expressed, among others, by the European Parliament and civil society. The European Ombudsman has also had an active role in this regard. In July 20I4, she presented a first set of suggestions to the Commission in relation to common negotiating texts, greater proactive disclosure of TTIP documents, and enhanced transparency around TTIP meetings. She also carried out an own-initiative inquiry into the matter and in January 2015 she produced ten further suggestions that should be taken into account by the European Commission. As a result of this pressure, the European Commission has doubled efforts to make TIPP negotiations more transparent (see its Communication titled 'Concerning transparency in TIPP negotiations', COM (20I4) 9052 final, and the European Commission's TIPP website, where relevant information is accessible: <http://ec.europa.eu/trade/policy/in-focus/ttip/>, accessed 2 October 2015. Some scholars have considered this is only an 
public authorities and stated "all actions relating to the rights of other men are wrong, if the maxims from which they follow are inconsistent with publicity" ${ }^{13} \mathrm{He}$ also maintained that as well as being a moral principle, it was also a legal one. So, he advocated considering transparency as a legal rule. What we will try to determine here is whether this is the case for contemporary International Law.

There is no universally accepted binding definition of corruption ${ }^{14}$. As underlined by the United Nations Office on Drugs and Crime (UNODC), attempts to develop a precise definition invariably encounter cultural, legal, criminological and, in many countries, political problems. ${ }^{\mathrm{IS}}$ The United Nations Convention against Corruption ${ }^{16}$ does not contain a definition, but mentions specific types or acts of corruption. Among them, money-laundering, bribery, embezzlement, misappropriation, illicit enrichment, abuse of functions, and trading in influence.

Various treaties have been also adopted at regional level aiming to tackle corruption. At European level, the Council of Europe Criminal Law Convention on Corruption ${ }^{17}$ mentions a variety of criminal acts (bribery, trading in influence, money laundering, different account offences) amounting to corruption. There is, however, a definition of corruption in Article 2 of the Council of Europe Civil Law Convention on Corruption. ${ }^{18}$ The Inter-American Convention against Corruption ${ }^{19}$ applies

example of the progressive eradication of secrecy in treaty negotiations: S. Schill, 'Transparency as a Global Norm in International Investment Law', Kluwer Arbitration Blog, text available at <http://kluwerarbitrationblog.com/blog/2014/o9/15/transparency-as-a-global-norm-in-international-investment-law/>, accessed 2 October 2015 .

ז3 I. Kant, Perpetual Peace. A Philosophical Essay (George Allen \& Unwin Ltd. and The Macmillan Company, London and New York, 1917), at 185 .

${ }^{14}$ As it has been pointed out by some scholars “(...) it seems as if we are dealing with a clearly delineated phenomenon. However, if we look at present and historical cases which have been considered corruption one finds frequently a mixture of bribery, self-enrichment, fraud, cronyism and mismanagement. This raises the question about the essence of corruption": P. C. van Duyne, 'Will Caligula Go Transparent? Corruption in Acts and Attitudes' I Foum on Crime and Society (200I) 73-98, at 73 .

Is See the United Nations Handbook on Practical Anti-Corruption Measures for Prosecutor and Investigators (2004), p. 23, text available at <https://www.unodc.org/pdf/crime/corruption/Handbook.pdf>, accessed 2 October 2015. As the European Commission stated in 2003 "there is no single uniform definition of all the constituent elements of corruption. Whereas one of the rather traditional definitions, followed by the World Bank and the non-governmental organization Transparency International, views corruption as "the use of one's public position for illegitimate private gains", it appears more appropriate to use a broader definition such as the one of the Global Programme against Corruption run by the United Nations, i.e. "abuse of power for private gain" and including thereby both the entire public and private sector": See the Communication from the Commission to the Council, the European Parliament and the European Economic and Social Committee, on a comprehensive EU policy against corruption (COM (2003) 317 final).

${ }^{16}$ Adopted 3I October 2003, entered into force 14 December 2005, text available at $<$ https://www.unodc.org/unodc/en/treaties/CAC/>, accessed 2 October 2015. For an analysis of the Convention see, e.g., R.R. Babu, 'The United Nations Convention against Corruption: A Critical Overview', 2006, available at SSRN <http://ssrn.com/abstract=891898>, accessed 2 October 2015; O. Brunelle-Quraishi, 'Assessing the Relevancy and Efficacy of the United Nations Convention against Corruption: A Comparative Analysis' 2 Notre Dame Journal of International and Comparative Law (200I) IOI-I66; Ph. Webb, 'The United Nations Convention against Corruption. Global Achievement or Missed Opportunity?’ 8 Journal of International Economic Law (2005) 19I-229 [DOI: 10.1093/jielaw/jgioo9].

${ }_{17}$ ECTS No.: 173 (adopted 2I January 1999, entered into force on I July 2002), text available at $<$ http://conventions.coe.int/>, accessed 2 October 2015.

I8 ECTS No.: 174 (adopted on 4 November 1999, entered into force I November 2003), text available at $<\mathrm{http}$ ///conventions.coe.int/>, accessed 2 October 2015. According to Art. 2, "corruption" means, for the purpose of the Convention, "requesting, offering, giving or accepting, directly or indirectly, a bribe or any other undue advantage or prospect thereof, which distorts the proper performance of any duty or behavior required of the recipient of the bribe, the undue advantage or the prospect thereof". 
to the acts of corruption listed in Article VI, but does not contain a definition of corruption. In the African context, a specific instrument has been adopted. The definition of corruption contained in Article I.I in the African Union Convention on Preventing and Combating Corruption ${ }^{20}$ refers to the "acts and practices including relating offences proscribed" in the Convention, and listed in Article 4.I.

Finally, as the European Commission for Democracy through Law (also known as the "Venice Commission" ${ }^{21}$ has emphasized, there has been a multitude of definitions or descriptions of "good governance" at international level. The notion of good governance was adopted by the World Bank in the late 1990's to establish the link between the quality of a country's governance system and its ability to promote sustainable economic and social development. Since then, other international institutions have used the notion to define different processes, frameworks, or again cultures in different contexts, such as corporate law, environmental law, economic law, sports law and even transitional justice. But, as Rudolf points out, what is not clear is whether the notion has any legal significance, and whether it has acquired a binding nature outside the framework of international treaties. ${ }^{22}$

The link between transparency, fighting against corruption and good governance is essential for this analysis. International Organizations and scholarship analysis has contributed to underline that link.

The Human Rights Council has repeatedly stressed that good governance at local and international levels, which includes among other elements fighting corruption and transparent government, plays an essential role in the promotion and protection of human rights and in the process of creating an environment conducive to their full enjoyment. ${ }^{23}$ And the United Nations General Assembly's Millennium Declaration of 2000 maintained that success in meeting development and poverty reduction goals depended inter alia "on good governance within each country" and "on good governance at the international level and on transparency in the financial, monetary and trading system"24.

\footnotetext{
19 Adopted 29 March 1996, entered into force 3 June 1997, text available at $<$ https://www.oas.org/juridico/english/treaties/b-58.html>, accessed 2 October 2015.

${ }_{20}$ Adopted II July 2003, entered into force on 5 August 2006, text available at $<$ http://www.au.int/en/sites/default/files/AFRICAN_UNION_CONVENTION_PREVENTING_COMBATING_CO RRUPTION.pdf>, accessed 2 October 2015. About the African Union Convention see N. J. Udombana, 'Fighting Corruption Seriously? Africa's Anticorruption Convention' 7 Singapore Journal of International \& Comparative Law (2003) 447-488.

${ }_{21}$ See its study 'Stocktaking on the Notions of "Good Governance" and "Good Administration", Study no. 470/2008, CDL-AD (200I) o09, text available at <http://www.eods.eu/library/VC.Stocktaking\%20On\%20The\%20Notions\%20Of\%20\% E2\%80\%9CGood\%20Governance\% $\mathrm{E}_{2} \% 80 \% 9 \mathrm{D} \% 20 . \mathrm{pdf}>$, accessed 2 October 2015 .

22 B. Rudolf, 'Is 'Good Governance' a Norm of International Law', in P.-M. Dupuy et al., Common Values in International Law. Essays in Honour of Christian Tomuschat (N.P. Engel Verlag, Kehl, 2006) 1007, at 1007.

${ }_{23} \mathrm{Cfr}$. Human Rights Council Resolution 7/71, on the role of good governance in the promotion and protection of human rights $(\mathrm{A} / \mathrm{HRC} / \mathrm{RES} / 7 / \mathrm{II})$.

24 GA Res. 55/2, I8 September 2000, at III. I3.
} 
In general, authors consider that transparency is enshrined in the broader notion of transparency, ${ }^{25}$ that it has been touted as a core attribute of good governance, ${ }^{26}$ that it is a prerequisite of good governance ${ }^{27}$ and one of the elements in the triad of good governance values. ${ }^{28}$ Lack of transparency in the judicial system has been quoted among the causes for corruption remaining unreported or not prosecuted. ${ }^{29}$ And according to the NGO Transparency International, "good governance is characterized as being participatory, accountable, transparent, efficient, responsive and inclusive, respecting the rule of law and minimizing opportunities for corruption". $3^{\circ}$

The objective of this paper is twofold. In the first part, I consider five specific issues to illustrate concrete developments at multilateral level. First, the analysis focuses on the role played by International Organizations in the fight against corruption. A significant number of international instruments have been adopted and international monitoring systems have been established to tackle both private and public corruption. Second, we examine how the right of access to information has been conceived as a means of promoting transparency and good governance. Third, we look at how transparency has been incorporated in emerging International Financial Law. Fourth, Global Administrative Law as a specific body of International Law promoting transparency and good governance is considered. Finally, there is an examination of how the pressure exerted by International Organizations on sport governing bodies to increase transparency and good governance has been crucial for the emergence of International Sports Law. Of course, these are not the only areas of International Law where transparency and good governance have flourished as contemporary paradigms or guides to conduct for States, International Organizations and even private parties. The topics discussed here may be considered only the tip of the iceberg. But in my opinion, they provide just enough discussion to pose an additional question. Thus, in the second part of this paper we take transparency as an example to analyze whether or not we are before a new rule of Public International Law and, if so, how its legal status, its addresses and the legal consequences for its breach can be determined. After addressing this question, some conclusions will be drawn on the role of fighting corruption and promoting transparency and good governance in contemporary International Law.

\section{INTERNATIONAL ACTION TO TACKLE CORRUPTION AND PROMOTE TRANSPARENCY AND GOOD GOVERNANCE: THE ROLE OF INTERNATIONAL ORGANIZATIONS}

${ }^{25}$ L. Hinojosa, 'Transparency in International Financial Institutions”, in Bianchi and Peters, supra n. I, at 77. See also: F. Weiss and S. Steiner, 'Transparency as an element of good governance in the practice of the EU and the WTO: Overview and comparison', 30 Fordham International Law Journal (2006) I545-1586.

26 D. Hovell, 'The deliberative deficit: Transparency, access to information and UN sanctions', in Bianchi and Peters, supra n. I, at 92.

${ }_{27}$ M. Augustyn and C. Monda, 'Transparency and Access to Documents in the EU: Ten Years on from the Adoption of Regulation I049/200I, II EIPAScope (20II) I7-20, available at <http://aei.pitt.edu/33492/I/20II09I2I03927_EipascopeSpecialIssue_Art2.pdf>, accessed 2 October 2015, at I.

${ }_{28}$ Along with information and accountability: C. Harlow, 'Global Administrative Law: The Quest for Principles and Values' i7 European Journal of International Law (2006) I87-2I4 [DOI: 10.1093/ejil/chi158], at I99.

29 I. Carr, 'Fighting Corruption through Regional and International Conventions: A Satisfactory Solution?' I5 European Journal of Crime, Criminal Law and Criminal Justice (2007) I2I-153 [DOI: 10.1163/092895607X209120], at I26.

30 Definition available at < https://www.transparency.org/glossary/term/governance>, accessed 2 October 2015. Emphasis added. 
Determining the starting point for this analysis is not an easy task. In my view, it can be assumed that transparency and fighting corruption are required conditions for the good governance of public and private affairs. And I will try to show how, due to the work of a variety of International Organizations, these three elements can be branded as "new purposes" of a growing number of sectors of Public International Law. Some of these developments are examined here.

\section{(I) The role of International Organizations in fighting corruption}

International Organizations have adopted a variety of initiatives and instruments imposing States Parties' obligations regarding the prevention and eradication of corrupt practices. ${ }^{3 \mathrm{r}}$

At the European level, the Council of Europe considers corruption to be a threat to democracy and the rule of law. In 1994, the European Ministers of Justice decided that corruption should be addressed jointly at European level.32 Three years later, the Committee of Ministers approved a Resolution containing twenty Guiding Principles on the fight against Corruption. ${ }^{33}$ In 1999, a specific monitoring mechanism, the Group of States against Corruption-GRECO, ${ }^{34}$ was set up and the abovementioned Criminal Law Convention on Corruption and Civil Law Convention on Corruption were opened to signature. In 2003, an Additional Protocol to the Criminal Law Convention on Corruption was adopted. ${ }^{35}$

At EU level, after the entry into force of the Lisbon Treaty, the primary legislation on the fight against corruption are Articles $67.3^{36}$ and $83.1^{37}$ of the Treaty on the Functioning of the European Union (TFEU). But different measures had already been adopted by the EU in this field before TFEU came into force. The Communication from the Commission to the Council, the European

35 An excellent survey of the main international instruments adopted in the fight against corruption can be found at $\mathrm{F}$. Jiménez García, La prevención y lucha contra el blanqueo de capitales y la corrupción. Interacciones evolutivas en un Derecho internacional global (Comares, Granada, 2015), at 90-153.

32 In September 1994 the Council of Europe creates a Multidisciplinary Group on Corruption (GMC) under the responsibility of the European Committee on Crime Problems and the European Committee on Legal Co-operation.

33 Resolution (97) 24, adopted 6 November 1997, text available at <https://wcd.coe.int/ViewDoc.jsp?id=593789\&>, accessed 2 October 2015. In this Resolution the Committee of Ministers of the Council of Europe declares that corruption represents a serious threat to the basic principles and values of the Council of Europe, undermines the confidence of citizens in democracy, erodes the rule of law, constitutes a denial of human rights and hinders social and economic development.

34 Relevant information about GRECO is available at <http://www.coe.int/t/dghl/monitoring/greco/default_en.asp >, accessed 2 October 2015. GRECO monitoring procedures include the collection of information through questionnaires, country visits enabling evaluation teams to solicit further information during high-level discussions with domestic stakeholders, and drafting of evaluation reports. These reports, which are examined and adopted by GRECO, contain recommendations to the evaluated countries in order to improve their level of compliance with the provisions under consideration. Measures taken to implement recommendations are subsequently assessed by GRECO under a separate compliance procedure.

35 ECTS No.: I9 (adopted I5 May 2003, entered into force I February 2005), text available at $<$ http://conventions.coe.int/>, accessed 2 October 2015 .

36 Establishing that "the Union shall endeavor to ensure a high level of security through measures to prevent and combat crime, racism and xenophobia, and through measures for coordination and cooperation between police and judicial authorities and other competent authorities, as well as through the mutual recognition of judgments in criminal matters and, if necessary, through the approximation of criminal laws".

37 According to this Art., the European Parliament and the Council may establish minimum rules concerning the definition of criminal offences and sanctions in the areas of particularly serious crime with a cross-border dimension. Corruption is explicitly mentioned as one of those offences. 
Parliament and the European Economic and Social Committee, on a comprehensive EU policy against corruption ${ }^{38}$ summarized the principal elements of a future EU anti-corruption policy. In addition, the European Commission released its first Anti-Corruption Report ${ }^{39}$ in February 20I4, providing for a comparative analysis of the situation in each Member State. Article 325 of the TFEU (replacing Article 280 of the European Community Treaty) is also relevant in the fight against corruption. This article establishes that the EU and the Member States shall counter fraud and any other illegal activities affecting the financial interests of the Union. Corruption is one of those illegal activities. Article 280 of the European Community Treaty served as the legal basis for the creation of the European Anti-Fraud Office (OLAF) ${ }^{40}$ in 1999. OLAF exercise the Commission's powers to carry out external administrative investigations for the purpose of strengthening the fight against fraud, corruption and any other illegal activity adversely affecting EU financial interests, as well as any other act or activity by operators in breach of EU provisions..$^{41}$ Also the Court of Auditors, established to audit the EU's finances, has important competences in this regard..$^{42}$

Relevant instruments have been adopted also by the Organization for Economic Co-operation and Development (OECD), including the Convention on Combating Bribery of Foreign Public Officials in International Business Transactions. ${ }^{43}$ The Convention establishes a monitoring mechanism for the OECD Working Group on Bribery to ensure full implementation of States Parties' international obligations.

As already noted, an Inter-American Convention against Corruption was adopted in 1996. The purposes of the Convention are:

"I. To promote and strengthen the development by each of the States Parties of the mechanisms needed to prevent, detect, punish and eradicate corruption, and

2. To promote, facilitate and regulate cooperation among the States Parties to ensure the effectiveness of the measures and actions to prevent, detect, punish and eradicate corruption in the performance of public functions and acts of corruption specifically related to such performance." 4

A Mechanism for Follow-Up on the Implementation of the Inter-American Convention against Corruption (MESICIC) was established in 2002. MESICIC supports the States Parties in the implementation of the obligations contained in the Convention through a process of reciprocal

${ }_{38}$ Supra n. I5.

39 Text available at <http://ec.europa.eu/dgs/home-affairs/what-we-do/policies/organized-crime-and-humantrafficking/corruption/anti-corruption-report/index_en.htm $>$, accessed 2 October 2015.

40 Commission Decision of 28 April 1999 establishing the European Anti-Fraud Office (OLAF), 1999/352/EC, ECSC, Euratom, Official Journal L 136, 31 May 1999. According to Art. I.a) of the Decision, the Office shall be responsible for carrying out internal administrative investigations intended to combat fraud, corruption and any other illegal activity adversely affecting the Community's financial interests.

4 Ibidem, Art. I.

42 See Arts. 285-287 of the TFEU. The Court of Auditors shall carry out the Union's audit. For this purpose, it shall examine the accounts of all revenue and expenditure of the Union. It shall also examine the accounts of all revenue and expenditure of all bodies, offices or agencies set up by the Union in so far as the relevant constituent instrument does not preclude such examination.

43 Adopted 17 December 1997, entered into force I5 February 1999, text available at <http://www.oecd.org/corruption/oecdantibriberyconvention.htm>, accessed 2 October 2015.

44 Art. II. 
evaluation. ${ }^{45}$ As a result of this evaluation processes, recommendations are formulated regarding those areas in which legal gaps are detected or in which further progress is perceived as necessary.

At universal level, UNODC leads international action against corruption. The Preamble to the United Nations Convention against Corruption underlines that corruption is no longer a local matter but a transnational phenomenon that affects all societies and economies, making international cooperation to prevent and control it essential. According to Article 5.I in the UN Convention, States Parties shall develop and implement or maintain effective, coordinated anti-corruption policies that promote the participation of society and reflect the principles of the rule of law, proper management of public affairs and public property, integrity, transparency and accountability. In my view, this article is another good example of the above-mentioned internationally assumed link between fighting corruption, transparency and good governance.

(2) Protection of the right to access to information as a means to improve transparency and good governance

Access to information held by public authorities is an internationally protected human right. It has been conceived as a means to improve transparency in public affairs, good governance and the quality of democracy ${ }^{46}$, as a companion of transparency. ${ }^{47}$ In this sense, transparency is conceived as a means of empowering the weak by giving them access to politically sensitive information, which can be wielded to encourage political change. $4^{8} \mathrm{~A}$ variety of developments in this regard can be assessed both at regional and universal levels.

The Inter-American Court of Human Rights and the European Court of Human Rights (ECHR) have both developed relevant case law regarding freedom of information. In Claude Reyes et al. vs. Chile, ${ }^{49}$ the Inter-American Court recognized the right to access information ${ }^{50}$ for the first time. The judgment has had a noteworthy influence both on ECHR case law ${ }^{\text {st }}$ and on General Comment no. 34

45 Country reports formulating concrete recommendations to States Parties have been adopted. The reports are available at < http://www.oas.org/juridico/english/mesicic_reports.htm>, accessed 2 October 2015.

46 See, e.g., A. Héritier, 'Composite Democracy in Europe: The Role of Transparency and Access to Information', Io Journal of European Public Policy (2003) 814-833 [DOI: 10.1080/1350176032000I24104]. According to Klaaren, "one way of understanding the relationship between the human right to information and transparency is to see the human right to information as a vehicle for increasing a certain amount of transparency": J. Klaaren, "The Human Right to Information and Transparency', in Bianchi and Peters, supra n. I, at 225.

47 Peters, supra n. 3, at 586.

$4^{8}$ K. M. Lord, The Peril and Promise of Global Transparency. Why the Information Revolution May not Lead to Security, Democracy, or Peace (State University of New York Press, New York, 2006), at 9I.

49 Judgment of I9 September 2006, Merits, Reparations and Costs, text available at $<$ http://www.corteidh.or.cr/docs/casos/articulos/seriec_I5I_ing.pdf>, accessed 2 October 2015.

so According to the Court, "the State's actions should be governed by the principles of disclosure and transparency in public administration that enable all persons subject to its jurisdiction to exercise the democratic control of those actions, and so that they can question, investigate and consider whether public functions are being performed adequately. Access to State-held information of public interest can permit participation in public administration through the social control that can be exercised through such access", Ibidem, paragraph 86.

${ }_{51} \quad$ An analysis of this influence can be found in Y. Fernández Vivas, 'La influencia de la sentencia de la CIDH "Claude Reyes contra Chile” en la jurisprudencia del TEDH’ 9 Eunomía. Revista en Cultura de la Legalidad (2015) $321-333$. 
of the Human Rights Committee (HRC) on Article 19 (freedom of opinion and expression).52 The purpose of the Council of Europe Convention on Access to Official Documents ${ }^{53}$ is, according to Article 2, to "guarantee the right of everyone, without discrimination on any ground, to have access, on request, to official documents held by public authorities."

At African level a specific monitoring mechanism has been created: The Special Rapporteur on Freedom of Expression and Access to Information was established by the African Commission on Human and Peoples' Rights by with the adoption of Resolution 7 I adopted during its $36^{\text {th }}$ Ordinary Session held from 23 November to 7 December 2004 in Dakar. In 2007, the Special Rapporteur adopted a Resolution on the Right to Access to Information ${ }^{54}$ and in April 20I3, the African Commission on Human and Peoples' Rights launched the Model Law on Access to Information in Africa aiming to guiding the development of new access to information legislation in African countries and reviewing the existing one. According to it: 55

"Access to information is of growing international and regional concern, and is a topic on which African States are increasingly under-taking legislative reform. Properly implemented access to information legislation holds the promise of fostering good governance by improving information management, and by enbancing transparency, accountability and greater participation of the populace in public affairs. By exposing corruption, maladministration and mismanagement of resources, increased transparency and accountability is likely to lead to better management of public resources, improve-ments in the enjoyment of socio-economic rights and to contribute to the eradication of under-development on the continent" ${ }^{56}$

The EU Charter of Fundamental Rights also contains related rights in Articles 4I (right to good administration) and 42 (right of access to documents). Also at EU level, Article 15.I of the TFEU establishes that in order to promote good governance and ensure the participation of civil society, the Union's institutions, bodies, offices and agencies shall conduct their work as openly as possible. Under paragraph 3 ,

"(a)ny citizen of the EU, and any natural or legal person residing or having its registered office in a Member State, shall have a right of access to documents of the Union's institutions, bodies, offices and agencies".

$52 \mathrm{CCPR} / \mathrm{C} / \mathrm{CG} / 34$, adopted on $\mathrm{I2}$ September 200I, text available at <http://www.ohchr.org/EN/HRBodies/CCPR/Pages/CCPRIndex.aspx>, accessed 2 October 20I5. The HRC maintains in this General Comment that art. 19, paragraph 2 of the International Covenant on Civil and Political Rights embraces a right of access to information held by public bodies. According to the Committee "to give effect to the right of access to information, States parties should proactively put in the public domain Government information of public interest. States parties should make every effort to ensure easy, prompt, effective and practical access to such information. States parties should also enact the necessary procedures, whereby one may gain access to information, such as by means of freedom of information legislation. The procedures should provide for the timely processing of requests for information according to clear rules that are compatible with the Covenant. Fees for requests for information should not be such as to constitute an unreasonable impediment to access to information. Authorities should provide reasons for any refusal to provide access to information. Arrangements should be put in place for appeals from refusals to provide access to information as well as in cases of failure to respond to requests" (paragraphs i8 and i9).

53 Adopted I8 June 2009 and not yet in force, text available at <http://conventions.coe.int/>, accessed 2 October 2015. The Convention has currently seven ratifications, and needs ten.

${ }_{54}$ The text of the Resolution is available at < http://www.oas.org/dil/access_to_information_IACHR_guidelines.pdf $>$, accessed 2 October 2015 .

55 Text available at <http://www.achpr.org/news/2013/04/d84>, accessed 2 October 2015.

56 Emphasis added. 
In fact, transparency and openness entered EU law and policies when the authors of the Treaty of Maastricht attached to it a declaration (No. 17) on the right of access to information which connected this right to "transparency of the decision-making process". 57 The right of access to information was later developed by Regulation (EC) no. I049/200I of the European Parliament and of the Council of 30 May 200 r regarding public access to European Parliament, Council and Commission documents. ${ }^{58}$ There is also relevant case-law of the European Union Court of Justice (ECJ) on the matter. ${ }^{59}$ In recent Case C-280/II P, the ECJ underlined the link between the right of access to documents of the EU Institutions and the democratic nature of those Institutions and the need of promoting transparency in the EU legislative process. ${ }^{60}$

The right of access to information has a specific meaning in the context of the so-called "transitional justice". ${ }^{6}$ In particular, it plays a relevant role in the context of implementation of the right to truth guaranteed to victims of gross human rights violations. ${ }^{62}$ Thus, the "Updated Set of principles for the protection and promotion of human rights through action to combat impunity", adopted in $2005,{ }^{63}$ refers to the measures that States should implement regarding preservation of and access to archives. ${ }^{64}$ In the same sense, as it is summarized in the "Study on the right to the truth" prepared by the Office of the United Nations High Commissioner for Human Rights ${ }^{65}$

"(a)ccess to information and, in particular, to official archives, is crucial to the exercise of the right to the truth. The importance of archives has been underlined by the independent expert to update the Set of Principles to reflect recent developments in international law and practice, including international jurisprudence and State practice and in the Set of Principles, which provides guidelines

57 OJ $1992 \mathrm{C}$ 19I/I. According to this Declaration transparency in the decision-making process strengthens the democratic nature of the institutions and the public's confidence in the administration.

58 OJ L I45, 3I May 200 I.

59 See, e.g., J. Heliskoski and P. Leino, 'Darkness at the Break of Noon: The Case-Law on Regulation no. IO49/200I on Access to Documents' 43 Common Market Law Review (2006) 735-78r; K. Leanerts, “In the Union We Trust”: TrustEnhancing Principles of Community Law' 4I Common Market Law Review (2004) 317-343; and S. Peers, 'The New Regulation on Access to Documents: A Critical Review' 2I Yearbook of European Law (200I) 385-442.

60 Judgment on Council of the European Union v. Access Info Europe, C-280/II P, EU:C:2013:67I. In this judgment, the ECJ reiterated that “(...) according to settled case-law, (...) in order to justify refusing access to a document, it is not sufficient, in principle, for the document to fall within an activity or an interest referred to in Article 4 of Regulation No I049/200I, as the institution concerned must also explain how access to that document could specifically and actually undermine the interest protected by an exception laid down in that provision paragraph.” (paragraph 72). Regarding the links between access to information and transparency in EU law, see: E. Guichot, Transparencia y acceso a la información en el Derecho europeo (Derecho Global, Sevilla, 20II).

${ }_{61}$ According to UN Secretary General this notion "comprises the full range of processes and mechanisms associated with a society's attempts to come to terms with a legacy of large-scale past abuses, in order to ensure accountability, serve justice and achieve reconciliation": Cfr. the Report of the Secretary-General on "The rule of law and transitional justice in conflict and post-conflicts societies" (S/2004/616, 23 August 2004).

62 At universal level, this right has been enshrined in Art. 24.2 of the UN Convention for the Protection of All Persons from Enforced Disappearance, 2716 UNTS 3 (adopted 20 December 2005, entered into force 23 December 20I0). On the right to truth see, e.g., D. Groome, Right to Truth in the Fight against Impunity, 29 Berkeley Journal of International Law (20II) 175-199 [DOI:I0.15779/Z38B35P].

63 E/CN.4/2005/IO2/Add.I, adopted 8 February 2005, text available at <http://daccess-ddsny.un.org/doc/UNDOC/GEN/Go5/109/00/PDF/G0510900.pdf?OpenElement>, accessed 2 October 2015.

${ }^{64}$ Principle 15 refers to measures for facilitating access to archives and Principle 17 contains specific measures referred to archives containing names.

65 E/CN.4/2006/91, adopted 8 February 2006, text available at <http://www.un.org/en/ga/search/view_doc.asp?symbol=E/CN.4/2006/9I>, accessed 2 October 2015. 
on access. It is also relevant to note the work done on this issue by the International Council on Archives in association with United Nations Educational, Scientific and Cultural Organization (UNESCO), and the handbook for NGOs they produced on archives and human rights". ${ }^{66}$

Non judicial and judicial international human rights bodies have also referred to the right to access to public information in this context. Of particular importance in this regard is the judgment of the Inter-American Court of Human Rights in Gomes Lund et al. ("Guerrilla de Araguaia") vs. Brazil, ${ }^{67}$ where the Court confirmed that all persons, including the next of kin of the victims of gross human rights violations, have the right to know the truth, and that, as a consequence of this, both they and the society must be informed of all that occurred in regard to those violations. In this sentence, the Court highlighted that,

"the existence of a regional consensus of States that comprise the Organization of American States on the importance of access to public information. Moreover, the necessity to protect the right to access public information has been the objective behind specific orders issued by the General Assembly of the OAS, wherein '[i]t urg[ed] States Parties to respect and ensure the access to public information of all persons and [to promote] the adoption of legal provisions or of another nature that are necessary to assure its recognition and effective application.' Likewise, the General Assembly, in diverse orders, considered that access to public information is an indispensable requisite for democracy to function, for increased transparency, and for good governance and that in a representative and participatory democratic system, the citizenry exercises its constitutional rights by means of wide-ranging freedom of expression and access to information" ${ }^{18}$.

In the framework of International Environmental Law, the right to access to environmental information has been enshrined in a variety of international instruments. Theoretically, there are various motivations for granting environmental information (and participation rights) to the public. One of them is to guarantee good governance of public affairs. ${ }^{69}$ As has been noted, "the duty to provide - and the right to obtain - access to information on the environment, whether to the public at large or to specific categories of persons (such as workers), is a recent but now firmly entrenched development in environmental law".$^{\circ}$ It is contained, for instance, in Principle io of the 1992 UN Rio Declaration on Environment and Development..$^{71}$ A large group of international binding instruments have been adopted, both at universal and European level, to regulate the exercise of this right. This is

66 Ibidem, paragraph 52.

${ }_{67}$ Judgment of 24 November 2010, Preliminary Objections, Merits, Reparations, and Costs, text available at <http://www.corteidh.or.cr/docs/casos/articulos/seriec_219_ing.pdf>, accessed 2 October 2015.

68 Ibidem, paragraph 198.

69 J. Jendroska, 'Public Information and Participation in EC Environmental Law; Origins, Milestones and Trend', in R. Macrory (ed.), Reflections on 30 years of EU Environmental Law. A High Level of Protection? (Europa Law Publishing, Groningen, 2006) 63, at 65-66.

$70 \mathrm{Ph}$. Sands, Principles of International Environmental Law (2nd ed., Cambridge University Press, Camdridge, 2003), at 852.

${ }^{71}$ Establishing that "at the national level, each individual shall have appropriate access to information concerning the environment that is held by public authorities, including information on hazardous materials and activities in their communities, and the opportunity to participate in decision-making processes", text available at < http://www.un.org/documents/ga/confi5I/aconfI5I26-Iannexi.htm>, accessed 2 October 20I2. It has been noted that the Rio Declaration is silent as to what information will be considered "appropriate", although some guidance may be found in Section 23.3 of Agenda 2I, which stipulates that "Individuals, groups and organizations should have access to information relevant to environment and development held by national authorities, including information on products and activities that have or are likely to have a significant impact on the environment, and information on environmental protection measures". 
exactly the purpose of the Convention on Access to Information, Public Participation in Decisionmaking and Access to Justice in Environmental Matters (Aarhus Convention)..$^{2}$

The Aarhus Convention, considered a fundamental step towards "environmental democracy",73 requires States Parties to ensure that public authorities make available to the public environmental information without an interest having to be stated, generally in the form requested, as soon as possible and at the latest within one month after the request has been submitted and without any unreasonable charge being made. ${ }^{74}$ Environmental information includes information on the state of the environment, but also on policies or measures taken, or on the state of human health and safety where this can be affected by the state of the environment. States are also required to guarantee the right to information by Article I3 of ILC's Draft articles on Prevention of transboundary harm from hazardous activities. ${ }^{75}$

The right of access to environmental information has been fully developed by EU Law. Directive $90 / 313 / E^{7} C^{76}$ was the first international instrument to create a right of access to environmental information. This Directive was replaced by Directive 2003/4/EC. ${ }^{77}$ And Regulation (EC) no. 1367/2006 gives effect to the requirements arising from European Community ratification of the Aarhus Convention. ${ }^{78}$ As the ECJ has clarified, EU law imposes the disclosure of information as a general rule. This means that public authorities should be permitted to refuse a request for environmental information only in a few specific and clearly defined cases and that the grounds for refusal should therefore be interpreted restrictively, in such a way that the public interest served by disclosure is weighed against the interest served by the refusal. ${ }^{79}$ Although various articles in the European Union Charter of Fundamental Rights recognize a right to information, ${ }^{80}$ none of them

72 216I UNTS 447 (adopted 25 June 1998, entered into force 30 October 200I). A number of earlier international treaties dealing with environmental issues had already required States to provide the public with information (see, for instance, Art. 3.8 of the 1991 Convention on Environmental Impact Assessment in a Transboundary Context; Art. 6 of the United Nations Framework Convention on Climate Change; Art. 9 of the 1992 OSPAR Convention for the Protection of the Marine Environment of the North-East Atlantic; and Chapter III of the 1993 Convention on Civil Liability for Damage Resulting from Activities Dangerous to the Environment).

${ }^{73}$ A. Pigrau Solé and S. Borràs Pentinat, 'Diez años del Convenio de Aarhus sobre el acceso a la información, la participación y el acceso a la justicia en materia de medio ambiente', in A. Pigrau Solé (dir), Acceso a la información, participación pública y acceso a la justicia en materia de medio ambiente: diez años del Convenio de Aarbus (Atelier, Barcelona, 2008) 2I, at $2 \mathrm{I}$.

74 Art. 4 (I), (2) and (9).

75 Adopted, on second reading, at ICL 2675th meeting held on in May 200I. According to the commentary to this article, it is "inspired by new trends in international law in general, and environmental law, in particular, of seeking to involve, in the decision-making processes, individuals whose lives, health, property and environment might be affected by providing them with a chance to present their views and be heard by those responsible for making the ultimate decisions".

76 Council Directive 90/313/EEC of 7 June 1990 on the freedom of access to information on the environment, OJ 1990 $\mathrm{L}_{15} 8 / 56$.

77 Directive 2003/4/EC of the European Parliament and of the Council of 28 January 2003 on public access to environmental information and repealing Council Directive 90/313/EEC, OJ $2003 \mathrm{~L}$ 4I/26.

${ }_{78}$ Regulation (EC) no. $1367 / 2006$ of the European Parliament and of the Council on the application of the provisions of the Aarhus Convention on Access to Information, Public Participation in Decision-making and Access to Justice in Environmental Matters to Community institutions and bodies, OJ $2006 \mathrm{~L} \mathrm{264/13.}$

79 Judgment in Office of Communications v. Information Commissioner, C-71/10, EU:C:20Ir:525, paragraph 22.

80 This is the case for Arts. II (freedom of expression and information), 27 (workers' right to information and consultation within the undertaking), and 42 (right of access to documents). As already noted, Art. 42 "seems to include also 
refers explicitly to environmental protection. This fact has been labelled as "intriguing", taking into account the role played by EU Institutions in the recognition of the right to environmental information. ${ }^{81}$

Also ECHR case-law has protected the right of access to environmental information. In general, the ECHR considers that Article Io $(\mathrm{I})^{82}$ of the European Convention of Human Rights does not apply in these cases, since this article prohibits public authorities from restricting a person from receiving information that others wish or may be willing to impart to him or her. ${ }^{83}$ However, Articles 2 and 8 have been considered by the Court in order to impose specific positive obligations on public authorities to ensure a right of access to environmental information in certain circumstances. ${ }^{84}$

\section{(3) The role of transparency in International Financial Law}

The role of transparency in different sectors of International Economic Law has been thoroughly analysed. Transparency is assumed to be transforming, among other sectors, International Investment ${ }^{85}$ and International Trade Law. ${ }^{86}$ International Financial Law can be considered the most

access to environmental information, although its scope is limited since it excludes non-citizen and non-resident natural or legal persons from the access to information". But, as this contradicts Art. 2 (2) (d) of the Aarhus Convention according to which "public authorities" also means the institutions of any regional economic integration organization, the EU institutions mentioned in Art. 42 should ensure access to environmental information for all: A. Kiss, 'Environmental and Consumer Protection', in S. Peers and A. Ward (eds), The EU Charter of Fundamental Rights. Politics, Law and Policy (London, Hart Publishing, 2014) at 257.

8I Ibidem, at 258 .

82 Guaranteeing the right to receive information.

83 Leander v. Sweden, ECHR (1987) Series A, No. 116, 74; Guerra and Others v. Italy, ECHR (1998) 26 EHRR $357,53$.

${ }^{84}$ See for instance Guerra and others v. Italy, supra n. 84, at 60; McGinley and Egan v. United Kingdom, ECHR (I998) 37 EHRR 82I, at 98; Roche v. United Kingdom, ECHR (2005) 42 EHRR 599, at 157; Vilnes and Others v. Norway, ECHR (2013) unreported, at 232; Brincat and others v. Malta, ECHR (2014) unreported, at IO2. This last judgment summarized the ECHR's position at follows: "The Court has also held on many occasions that the State has a positive duty to take reasonable and appropriate measures to secure an applicant's rights under Article 8 of the Convention (see, among many other authorities, López Ostra, cited above, $₫ 5$ I, Series A no. 303; Powell and Rayner v. the United Kingdom, 2I February 1990, \$ 4I, Series A no. 172; and, more recently, Di Sarno and Others v. Italy, no. 30765/08, § 96, I0 January 20I2). In particular, the Court has affirmed a positive obligation of States, in relation to Article 8, to provide access to essential information enabling individuals to assess risks to their health and lives (see, by implication, Guerra and Others, cited above, $\$ \$ 57-60$; López Ostra, cited above, $\$ 55$; McGinley and Egan, cited above, $\$ \$ 98$-104; and Roche, cited above, $\$ \$ 157^{-69)}$. In the Court's view, this obligation may in certain circumstances also encompass a duty to provide such information (see, by implication, Guerra and Others, cited above, $\$ \$ 57-60$; and Vilnes and Others, cited above $\$ 235$ ). It has also recognised that in the context of dangerous activities, the scopes of the positive obligations under Articles 2 and 8 of the Convention largely overlap (see Budayeva and Others, cited above, $\$$ I33). Indeed, the positive obligation under Article 8 requires the national authorities to take the same practical measures as those expected of them in the context of their positive obligation under Article 2 of the Convention (see Kolyadenko and Others, cited above, $\$ 216$ )", at IO2.

85 According to Schill "secrecy in treaty negotiations and confidentiality in dispute settlement, two hallmarks of investment law so far, are eroding". For this expert, "four developments are noteworthy: I) new approaches to treaty negotiation by the EU Commission in the Transatlantic Trade and Investment Partnership (TTIP); 2) the UNCITRAL Rules on Transparency; 3) the use of freedom of information acts; and 4) the contribution of scholarship": Schill, supra n. I2. See also: J. A. Maupin, 'Transparency in International Investment Law: The Good, the Bad and the Murky', in Bianchi and Peters, supra n. I, at I42. It is also noteworthy that GA Res. 69/II6, I8 December 20I4, adopted the United Nations Convention on Transparency in Treaty-based Investor-State Arbitration. The Convention opened for signature in Mauritius, on 17 March 2015 and will enter into force six months after the date of deposit of the third instrument of ratification, acceptance, approval or accession (see Arts. 7 (I) and 9 (I). 
recent indicator of this tendency. The 2008 global financial crisis has strengthened cooperation on global macroeconomic issues and financial surveillance. A new period for International Financial Law started in $2008,{ }^{87}$ when States and International Organizations agreed to reinforce the role of International Law in protecting financial stability and maintaining order in the world financial system. ${ }^{88}$ And transparency is, as an essential element of this new regulation, "a priority on the agenda of regulators around the world" $" 8$ and a pursued goal at institutional, procedural and substantive levels.

On 2 April 2009, the G-20 adopted a Declaration on strengthening of the financial system in which the leaders declared that their guiding principles were strengthening transparency and accountability of the financial sector, enhancing sound regulation, promoting integrity in financial markets and reinforcing international cooperation..$^{\circ}$ Revision of Basel II Framework or the approval of a variety of Codes of Ethics and Disclosure at different levels seek to secure transparency in financial matters.

At EU level, in $2010 \mathrm{EU}$ institutions referred to transparency for creating a European System of Financial Supervision..$^{91}$ More recently, hard law instruments ${ }^{92}$ have been approved both to consolidate

86 P. Delimatsis, 'Institutional Transparency in the WTO', in Bianchi and Peters, supra n. I, at II2. See also: P. Ala'i and M. D'orsi, 'Transparency in International Economic Relations and the Role of WTO', in P. Ala'i and R. G. Vaughn (eds), Research Handbook on Transparency (Edward Elgar Publishing, Cheltenham, 2014) 368.

87 As it has been said, "with growing financial globalization, international financial law has increased in significance and profile, especially in the wake of the global financial crisis of 2008 and the ongoing European financial crisis": D. Arner and U. Ashraf, 'International Financial Law', in T. Carty (ed.), Oxford Bibliographies in International Law (June 25, 2013), available at <http://www.oxfordbibliographies.com/view/document/obo-9780199796953/obo-9780199796953-0022.xml>, accessed 2 October 2015

${ }_{88}$ M. López Escudero, 'La protección de la estabilidad financiera como bien público global', in N. Bouza, C. García and A.J. Rodrigo (eds), La gobernanza del interés público global. XXV Jornadas de la Asociación Española de Profesores de Derecho Internacional y Relaciones Internacionales (Tecnos, Madrid, 2015), at 657-658.

89 C. Kaufman and R.H. Weber, 'The Role of Transparency in Financial Regulation', I3 Journal of International Economic Law (2010) 779-797 [DOI: 10.1093/jiel/jgq037], at 780 .

90 The text of the Declaration is available at <http://www.g2o.utoronto.ca/2009/2009ifi.html $>$, accessed 2 October 2015.

91 See paragraph 9 of the Preamble to the European Parliament and Council Regulation rog2/20I0 of 24 November 2010 on European Union macro-prudential oversight of the financial system and establishing a European Systemic Risk Board (OJ 2010 L 33I/I); paragraphs II, 26, 27 and 5I of the Preamble, and Arts. I (5) (b), 9 (I) and 8I (2) (f) of the European Parliament and Council Regulation 1093/2010 of 24 November 2010 establishing a European Supervisory Authority (European Banking Authority), amending Decision No 716/2009/EC and repealing Commission Decision 2009/78/EC (OJ 2010 L 33I/I2); paragraphs 10, 25, 26 and 5I of the Preamble, and Arts. I (6) (b), 9 (I) and 8I (2) (f) of the European Parliament and Council Regulation 1094/2010 of 24 November 2010 establishing a European Supervisory Authority (European Insurance and Occupational Pensions Authority), amending Decision No 716/2009/EC and repealing Commission Decision 2009/79/EC (OJ 2010 L 33I/48); and paragraphs II, 26, 27 and 5I of the Preamble, and Arts. I (5) (b), 9 (I) and 8I (2) (f) of the European Parliament and Council Regulation 1095/2010 of 24 November 2010 establishing a European Supervisory Authority (European Securities and Markets Authority), amending Decision No 716/2009/EC and repealing Commission Decision 2009/77/EC (OJ 2010 L 33I/84).

92 López Escudero, supra n. 88, at 671. 
a banking union ${ }^{93}$ and to adopt a Single Rulebook, seeking to lay down capital requirements for banks, ensure better protection for depositors and regulate the prevention and management of bank failures. ${ }^{94}$

But transparency obligations have reached not only States or banks, but also International Organizations themselves. Hinojosa has concluded that, in this context, "a higher degree of institutionalization calls for a more coherent and open transparency policy, as more structured institutions have at their disposal the appropriate resources and are more easily subject to pressure by the civil society". ${ }^{95}$ Thus, he considers International Monetary Fund and the World Bank are clearly more transparent than informal cooperation fora such as the G-20 or the Financial Stability Board. ${ }^{6}$

\section{(4) Transparency and good governance in Global Administrative Law}

Contemporary Public International Law increasingly regulates not only the relationship between States, but also the way State power is exercised internally regarding the constitutional and administrative structures of the States. ${ }^{97}$ As part of a global administrative space, domestic administrations have been required by International Organizations, ${ }^{98}$ and also by international human rights bodies ${ }^{99}$ to adapt internal administrative processes and structures to internationally imposed standards.

93 The bank union relies on a Single Supervisory Mechanism led by the European Central Bank (ECB) and a Single Resolution Mechanism for banks. According to paragraph 58 of the Preamble of Council Regulation IO24/2013 conferring specific tasks on the ECB concerning policies relating to the prudential supervision of credit institutions (OJ 20I3 L 287/63) establishes that the ECB should comply with the principle of transparency when implementing its tasks.

94 European Parliament and Council Directive 2013/36 of 26 June 2013 on access to the activity of credit institutions and the prudential supervision of credit institutions and investment firms, amending Directive 2002/87/EC and repealing Directives 2006/48/EC and 2006/49/EC (OJ 2013 L 176/338), European Parliament and Council Regulation 575/2013 of 26 June 2013 on prudential requirements for credit institutions and investment firms and amending Regulation (EU) No 648/20I2 (OJ 2013 L 176/I), European Parliament and Council Directive 2014/49 of I6 April 2014 on deposit guarantee schemes (OJ 2014 L 173/I49), and European Parliament and Council Directive 2014/59 of I5 May 2014 establishing a framework for the recovery and resolution of credit institutions and investment firms and amending Council Directive 82/89I/EEC, and Directives 200I/24/EC, 2002/47/EC, 2004/25/EC, 2005/56/EC, 2007/36/EC, 201I/35/EU, 2012/30/EU and 2013/36/EU, and Regulations (EU) No I093/2010 and (EU) No 648/2012, of the European Parliament and of the Council (OJ 2014 L 173/190) are parts of this Single Rulebook. They underline the importance of good governance structures and transparency for regaining the trust of citizens of the Union in the financial sector.

95 Hinojosa, supra n. 25, at IIO.

96 Ibidem. Paradoxically, these non-official fora are gaining importance in the framework of the current international economic crisis, while traditional economic International Organizations are being marginalized: A. Manero Salvador, ‘Gobernanza o desgobierno en las relaciones económicas internacionales?’ LXVI Revista Española de Derecho Internacional (2014) 155 -170.

97 Rudolf, supra n. 22, at 1008.

98 As it has been noticed, "for many developing countries, probably the most influential examples in this category are the Bretton Woods institutions. The World Bank's policies on good governance, whether designated as "advice" or as conditions of financial aid to developing countries, have generated extensive codes of principles and rules for the organization and procedures of domestic administration-ranging from measures to combat corruption to practices of greater transparency and procedural guarantees for market actors. Given the dependence of many countries on aid and external finance, these World Bank norms have transformed, or are in the process of transforming, domestic administration in large parts of the world. Comparable conditions imposed by the IMF on financial assistance to developing countries have had similar effects": B. Kingsbury, N. Krisch and R. B. Stewart, 'The Emergence of Global Administrative Law', 68 Law and Contemporary Problems (2005) 15-61, at 28.

99 The ECHR has played a relevant role in this regard, developing "a rich jurisprudence on domestic administrative procedures, especially on domestic review mechanisms": Ibidem. 
In this context, Global Administrative Law has been defined as the body of International Law covering "all the rules and procedures that help ensure the accountability of global administration, and it focuses in particular on administrative structures, on transparency, on participatory elements in the administrative procedure, on principles of reasoned decision-making, and on mechanisms of review". ${ }^{100}$ And fighting corruption and promoting transparency and good governance can be labelled as new functions of Public International Law enshrined in the context of a Global Administrative Law in status nascendi whose rules and principles apply both to State and international authorities and bodies. ${ }^{\text {Ior }}$ In this sense, control of corruption and transparency has been proposed as part of a set of global administrative law tools that can be clustered around good governance. ${ }^{\mathrm{I} 2}$ And transparency has been considered a global standard imposed by Global Administrative Law that has permeated all international institutional structures. ${ }^{103}$

(5) Transparency, good governance and the fight against corruption in sport: The quest for an International Sports Law

For a long time, the sports system has been conceived as a self-contained regime where public law and State authorities did not have a clear role to play. Private sports organizations argue for the so-called "specificity of sport" as a way to preserve regulatory autonomy and maintain in force private sporting rules, their own Lex Sportiva, even when they are in breach of essential principles of public law typically enshrined in International Law. The emergence of private mechanisms of settling sports disputes through national and international sports arbitration tribunals -being the Court of Arbitration for Sport (CAS) ${ }^{104}$ the supreme instance of this system- seeks to avoid the intervention of national and supranational courts. But in the last few years, sports governing bodies have been challenged by strong demands from both national and international public authorities to increase their levels of legal scrutiny, democracy, transparency and respect for fundamental rights and their efforts against corruption. ${ }^{105}$

Ioo Ibidem.

ror "In the course of the last few years, numerous attempts have been made to solve the problem of an emerging transnational legal order that still significantly lacks both democratic legitimacy and transparency": Weiss and Steiner, supra n. 25 , at 1545 .

Ior D. Esty, 'Good Governance at the Supranational Scale: Globalizing Administrative Law', ins Yale Law Journal (2006) I490-I562 [DOI: $10.2307 / 20455663$ ], at 1496.

${ }_{103}$ C. I. Fuentes, 'Transparency as a Global Goal: Towards a Unity of Principles in Global Administrative Law', (September 15, 2008), available at <http://dx.doi.org/10.2139/ssrn.I134122>, accessed 2 October 2015. According to this author, "transparency is a necessity in every single administrative entity, both at the national and international level (...) it is evident that transparency is indeed a global goal”, at 6.

${ }_{104}$ CAS has the responsibility of resolving disputes arising in the context of sport by arbitration and/or mediation pursuant to their own procedural rules. About this institution see B. Simma, 'The Court of Arbitration for Sport', in K.-H. Böckstiegel et al., (eds.), Völkerrecht. Recht der Internationalen Organisationen. Weltwirtschaftsrecht. Festschrift für Ignaz Seidl-Hobenveldern (Heymann, Colonia 1988) 573-585.

Ios One of the latest "scandals" regarding corruption in sports concerns football ruling body FIFA President, Joseph Blatter. The office of the Swiss attorney general had recently decided to open proceedings against him "on suspicion of criminal mismanagement" and "suspicion of misappropriation". Nevertheless, corruption in sports goes beyond economic corruption. Thus, doping or match fixing, for example, are generally included among the corrupt practices that should be prevented, eradicated and punished. Diverse international treaties have been adopted in this regard. The European Anti- 
The pressure exerted in this regard by International Organizations on non-governmental sports organizations, namely the International Olympic Committee (IOC), the World Anti-Doping Agency (WADA) and International Federations (IF's), has generated a public international sport corpus iuris, ${ }^{106}$ where demands for transparency and good governance play a key role. Both the Council of Europe and the EU have played an active role in this regard. ${ }^{107}$

At EU level, ${ }^{108}$ the European Commission has defined good governance as a condition for the autonomy and self-regulation of sports organization $s^{109}$ and has considered that there are "inter-linked principles that underpin sport governance at European level, such as autonomy within the limits of the law, democracy, transparency and accountability in decision-making, and inclusiveness in the representation of interested stakeholders". ${ }^{\text {ro }}$ An EU Expert Group on Good Governance was established on the basis of the Council Resolution on an EU Work Plan for Sport 20II-20I4. ${ }^{\mathrm{III}}$ In October 20I3, the Expert Group adopted recommendations on the Principles for Good Governance of

Doping Convention (CETS No.: 135, adopted 16 November 1989, entered into force 3 March 1990, text available at <http://conventions.coe.int/>, accessed 2 October 2015), and the International Convention against Doping in Sport (adopted 19 October 2005, entered into force I February 2007, text available at <http://portal.unesco.org/en/ev.phpURL_ID=31037\&URL_DO=DO_TOPIC\&URL_SECTION=20I.html $>$, accessed 2 October 2015) are two examples at regional and universal levels in the fight against doping in sports.

${ }^{106}$ According to Foster, a distinction between "international" and "global" sports law could be made. He defines "international sports law" as "the principles of international law applicable to sport", and global sports law "as a transnational autonomous legal order created by private global sport institutions that govern international sports”: K. Foster, 'Is There a Global Sports Law?', 2 Entertainment Law (2003) I-I8, at 2. About the concept of "International Sports Law" see J.A.R. Nafziger, 'International Sports Law: A reply of characteristics and trends' 86 American Journal of International Law (1992) 489-518, and A. Wax, 'Public International Sports Law: A "Forgotten Discipline”, in R.C.R. Siekmann and J. Soek (eds), Lex Sportiva: What is Sports Law? (T.M.C. Asser Press, The Hague, 2012) 287-297.

107 On the occasion of the 13th Council of Europe of Ministers responsible for Sport held on I8 September 20I4, the Ministers adopted a Resolution reaffirming the importance of European co-operation in sport between the European Union and the Council of Europe on, among other issues, good governance in sports. The text of the Resolution is available at <https://www.coe.int/t/dg4/epas/resources/Macolin-20I4/MSLI3_Iorev_Adopted-resolutions.pdf>, accessed 2 October 2015.

${ }_{108}$ Simply with the entry into force of the Treaty of Lisbon in December 2009, the EU acquired a specific competence for sport. Art. 6 of the TFEU mentions sport as one of the policy fields where the organization has competence to support, coordinate or supplement the actions of its Member States. Under Art. 165 of the TFEU, EU action regarding sport shall be aimed at "developing the European dimension in sport, by promoting fairness and openness in sporting competitions and cooperation between bodies responsible for sports, and by protecting the physical and moral integrity of sportsmen and sportswomen, especially the youngest sportsmen and sportswomen." On the incorporation of this competence for sport in the Lisbon Treaty see: B. García and S. Wheaterill, "Engaging with the EU in order to Minimize its Impact: Sport and the Negotiation of the Treaty of Lisbon', I9 Journal of European Public Policy (2012) 238-256 [DOI:10.1080/13501763.2011.609710].

rog Autonomy, i.e. self-organization and self-regulation, have traditionally characterized the world of sport. At EU level, the autonomy of sport activity was formally recognized by the Nice Declaration on 'the specific characteristics of sport and its social function in Europe, of which account should be taken in implementing common policies' annexed to the Presidency Conclusions of the Nice European Council Meeting held in 2000.

ro See the Communication from the Commission to the European Parliament, the Council, the European Economic and Social Committee and the Committee of Regions "Developing the European Dimension in Sport", COM (2OII) I2 final, at 4.I.

III Council and the Representatives of the Governments of the Member States, meeting within the Council, Resolution on a European Union Work Plan for Sport for 20II-20I4, OJ 20II C 162/I. The Work Plan invited Member States, the Council and the Commission to foster the integrity of sport, in particular through the fight against doping and match-fixing and by promoting good governance. 
Sport in the EU ${ }^{112}$ and presented them to the EU Council. ${ }^{\mathrm{II} 3}$ As already underlined, 'good governance' has become an important topic within EU institutions. ${ }^{\mathrm{II}}$

The Council of Europe has also actively fostered good governance in sports. Diverse resolutions have been adopted in this regard. ${ }^{\mathrm{II}}$ But it is noteworthy that the obligation of promoting good governance in sport has been also incorporated to hard law instruments. Thus, the European Convention on the Manipulation of Sports Competitions ${ }^{\mathrm{II}}$ establishes that each Party shall encourage sports organizations and competition organizers to adopt and implement rules to combat the manipulation of sports competitions as well as principles of good governance. ${ }^{\mathrm{II} 7}$

\section{TAKING TRANSPARENCY AS AN EXAMPLE: CAN IT BE CONSIDERED A NEW RULE OF PUBLIC INTERNATIONAL LAW?}

Fighting corruption and promoting transparency and good governance are obligations contained in soft law and even hard law international instruments. The content of these obligations are contextdependent. In this sense, I think we can conclude that certain sectors of International Law imposes concrete obligations regarding the fight against corruption and the promotion of transparency and good governance. ${ }^{\mathrm{II} 8}$ And some of those obligations are hard law obligations, that is, the ones found in international treaties or binding resolutions of international organizations.

I2 Available at < http://ec.europa.eu/sport/library/policy_documents/xg-gg-201307-dlvrbl2-sept20I3.pdf>, accessed 2 October 2015. Principle io refers to transparency and accountability.

II3 During the meeting held in Brussels on 25 and 26 November 2013, the European Council discussed the topic of good governance in sports. Although, in general, member States considered that the autonomy of sports organizations should be respected, some of them declared that they should intervene if those organizations receive public funding and do not respect good governance principles.

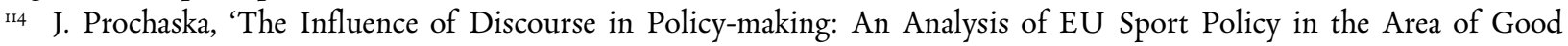
Governance', Paper prepared for UACES 44th annual conference, Cork 20I4, text available at < http://www.uaces.org/documents/papers/I40I/prochaska.pdf>, accessed 2 October 20I5, at I.

in See, e.g., Recommendation Rec (2005) 8 of the Committee of Ministers to member states on the principles of good governance in sport, adopted on 20 April 2005, text available at $<$ https: $/ /$ wcd.coe.int $/$ ViewDoc.jsp? id=850I89\&Site $=$ CM $>$ accessed 2 October 2015. The Committee of Ministers "recommends that the governments of member states adopt effective policies and measures of good governance in sport, which include as a minimum requirement: democratic structures for non-governmental sports organizations based on clear and regular electoral procedures open to the whole membership; organization and management of a professional standard, with an appropriate code of ethics and procedures for dealing with conflicts of interest; accountability and transparency in decision-making and financial operations, including the open publication of yearly financial accounts duly audited; and fairness in dealing with membership, including gender equality and solidarity."

II6 CETS No. 215 (adopted I8 September 2014, not yet in force, text available at $<$ http://conventions.coe.int/ $>$, accessed 2 October 2015). After the removal from the Register of the ECJ of the request for an Opinion under Art. 2I8 (II) of the TFEU made by Malta, and decided by the President of the Court on I September 2015 (EU:C:2015:607), there is no legal obstacle for the ratification of the Convention by the EU. In fact, the European Commission had adopted a Proposal for a Council Decision on the signing, on behalf of the European Union, of the Council of Europe Convention on the manipulation of sports competitions with regard to matters not related to substantive criminal law and judicial cooperation in criminal matters on 2 March 2015 (COM/2015/086 final). In the meantime, two EU Member States, Poland and Portugal have ratified the Convention.

II7 Art. 7 (I).

Ir8 Recently, the UNGA has included references to transparency in its resolutions on The Rule of Law at the National and International Levels, adopted on yearly basis since the inclusion of this item in the provisional agenda of the sixty-first session of the UNGA, in 2006. GA Res. 69/123, I8 December 2014, recalls "the commitment of the Member States to take all 
But can we go beyond this conclusion? Are these obligations contained in general rules or principles of International Law? Taking transparency as an example: Is it an obligation contained in a general rule of International Law? ${ }^{119}$ What is the legal status of a possible "global transparency norm" ? ${ }^{120}$ Is there an "overarching international legal prescription for transparency" ? ${ }^{121}$ Various issues must be addressed before answering these questions. ${ }^{122}$

(I) The legal nature of an emerging 'global transparency norm'

Examination of the legal nature of this alleged obligation compels to refer to Article 38 (I) of the Statute of the International Court of Justice (ICJ). ${ }^{\mathrm{I} 3}$ Still if this reference to the "classic boxes (...) does not tell us much about the state of international law and its power to influence the behaviour of internationally relevant actors". ${ }^{124}$

Transparency is seen as a public law paradigm aiming to provide good governance and enhance international legal system's legitimacy and effectiveness ${ }^{125}$ and has been included as a conventional obligation in a significant number of international treaties, ${ }^{\mathrm{I} 2} 6$ but also in non-binding instruments. Whether "no one has (so far) had the temerity to characterize transparency as a rule of customary international law" ${ }^{127}$, which would require a general practice of transparency accepted as law, some

necessary steps to provide fair, transparent, effective, non-discriminatory and accountable services that promote access to justice for all, including legal aid, encourages further dialogue and the sharing of national practices in strengthening the rule of law through access to justice, including with regard to legal aid, where appropriate, in both criminal and civil proceedings, and in this regard stresses the need to intensify the assistance extended to Governments upon their request" (at I4).

I9 As Bianchi recalls, "( $\mathrm{t}$ )ransparency is not immediately associated with international law. The world of international diplomacy and high politics has long been depicted as secretive and enigmatic, far removed from the public's eye": Bianchi, supra n. 4 , at 3 .

${ }_{\text {I20 }}$ Peters, supra n. 3, at 536 .

I2I Ibidem, at 583 .

${ }^{122}$ Although what I am addressing here are legal questions, the concept of transparency has been also "analyzed extensively under such disciplines as game theory, information theory, development theory and political economy": W.B.T. Mock, 'An Interdisciplinary Introduction to Legal Transparency: A Tool for Rational Development' I8 Dickinson Journal of International Law (2000) 293-304, at 294. I am also aware that "the concept of transparency has spread imperialistically out of the good governance canon and into popular parlance". A funny story illustrates this affirmation of Th. N. Hale and A.-M. Slaughter: "Riding a train between Princeton and New York, the ethicist Peter Singer found himself seated next to a talkative man. After answering many questions about his profession, Singer finally managed to enquire as to his fellow traveler's occupation. "I'm a transparency maintenance worker," the man replied. Thinking he had discovered an advocate of truth and responsibility, Singer excitedly asked his seatmate what institution or organization he monitored. Confused, the man replied, "I wash windows.": Th. N. Hale and A.-M. Slaughter, 'Transparency: Possibilities and Limitations', 30 Fletcher Forum of Word Affairs (2006) I53-163, at 153.

${ }_{123}$ Adopted 26 June 1945, entered into force 24 October 1945, text available at < http://www.icjcij.org/documents/index.php? $\mathrm{pI}=4 \& \mathrm{p}_{2}=2 \& \mathrm{p}_{3}=0>$, accessed 5 October 2015. According to this Art.: "The Court, whose function is to decide in accordance with international law such disputes as are submitted to it, shall apply: a. international conventions, whether general or particular, establishing rules expressly recognized by the contesting states; b. international custom, as evidence of a general practice accepted as law; c. the general principles of law recognized by civilized nations. $d$. $d$. subject to the provisions of Article 59, judicial decisions and the teachings of the most highly qualified publicists of the various nations, as subsidiary means for the determination of rules of law".

${ }_{224}$ Peters, supra n. 3, at 586.

${ }^{125}$ Bianchi, supra n. 4, at 5 .

${ }^{126}$ Environmental International Law, International Adjudication, and International Investment Law constitutes good examples in this regard: Peters, supra n. 3, at 583-384.

${ }^{127}$ Bianchi, supra n. 4, at 5 . 
scholars have underlined the existence of "abundant transparency practices" and have confirmed that "there would seem to be a relevant opinion iuris". ${ }^{228}$ Some authors argue that, in particular contexts, it has emerged as a general principle of law. ${ }^{\text {I29 }}$ Again, a transparency obligation would be enshrined in Environmental or Economic International Law, even if only as a secondary or complementary principle. Not having a concrete content, it does not prescribe, permit, or prohibit any specific action. It is more a kind of meta-legal principle, a normative prescription, which is useful for guiding normative processes and interpreting legal rules.

In short, the blurry, broad, and vague features of the concept of transparency make extremely difficult its characterization as a global norm of hard international law. ${ }^{\mathrm{I} 30}$ In any case, in order to be legally operative, it should satisfy some additional requirements.

(2) On the content and addresses of this 'global transparency norm'

Firstly, in order to generate a legal obligation, the content of this principle/norm/rule should be sufficiently precise. Again, this is context-dependent. Transparency has different meanings and turns into different prescriptions if we take it, for example, as a rule in the field of the fight against corruption or as a core goal regarding access to information. In general, an internationally imposed transparency obligation implies the disclosure of information relating to political decisions, procedures, decision-making processes, rules, actions, and the mode of functioning of the addressees.

Secondly, the addressees of the international obligation should be clarified. Who should be transparent? Who are the obligees and the beneficiaries? Both should be identified.

As we have examined, international transparency obligations seem to extend predominantly to States. Transparency requests have traditionally served to monitor State compliance with International Law. ${ }^{\mathrm{I} I}$ And International Organizations have promoted, even forced, State transparency, sometimes through international convention regimes. ${ }^{132}$ But we can also verify an increasingly effort made by International Organizations to make their decisions and procedures more transparent and accessible to the public. ${ }^{133}$ Finally, transparency requirements have reached non-state international

${ }_{128}$ Peters, supra n. 3, at 584 .

${ }_{129}$ Bianchi, supra n. 4 , at 5 .

r3o Peters accepts that maybe it can never become one. "But", she adds, "this finding might be of little relevance. Maybe the classic boxes, the 'sources' in terms of article 38 ICJ-Statute, do not tell us much about the state of international law and its power to influence the behavior of internationally relevant actors": Peters, supra n. 3, at 585-586.

I3I Ibidem, at 549 .

${ }^{132}$ For example, art. 2 of the Council of Europe Convention on Access to Official Documents states that each Party shall take the necessary measures in its domestic law to give effect to the provisions for access to official documents set out in the Convention: supra, note 49.

${ }^{133}$ See M. Donaldson and B. Kingsbury, 'The Adoption of Transparency Policies in Global Governance Institutions: Justifications, Effects, and Implications', 9 Annual Review of Law and Social Science (2013) II9-I47. The 'constitutionalization' of transparency in the EU framework constitutes a paradigmatic example in this regard. According to art. I of the Treaty on European Union, decisions will be taken "as openly as possible". And art. II states that "I. The institutions shall, by appropriate means, give citizens and representative associations the opportunity to make known and publicly exchange their views in all areas of Union action. 2. The institutions shall maintain an open, transparent and regular dialogue with representative associations and civil society. 3. The European Commission shall carry out broad consultations with parties concerned in order to ensure that the Union's actions are coherent and transparent". 
actors. ${ }^{\mathrm{I} 4}$ In EU Law, Banking Union secondary legislation cited above applies to all banks in the Eurozone. Regarding International Sports Law, most resolutions adopted at EU or Council of Europe framework try to influence the behaviour of private sports national and international authorities. ${ }^{\mathrm{I}}{ }^{35}$

The legal beneficiaries of transparency are, once again, context-dependent. The duty to inform to other States ${ }^{136}$ either in case of imminent disaster or of potential damage to be caused by certain activities is enshrined in a general principal of International Environmental Law. ${ }^{137}$ And in Disarmament Law "the legal schemes are designed to ensure that information on arms is made available to other States but not to the general public" ${ }^{{ }_{13} 8}$. Of course, the individuals integrate also the circle of beneficiaries of transparency.

(3) On the consequences of a breach of transparency obligations imposed by International Law

Finally, it has to be determined if any sanction would be imposed against those who breach transparency obligations. Which kinds of sanctions are imposed, who imposes them and through which kind of mechanisms are also interesting questions that have to be addressed. But they do not have a unique answer. And more importantly, since transparency is perceived as a positive goal by states and other international actors, they are more likely to take into account the reputational consequences of a violation and increase compliance. ${ }^{139}$

${ }^{\mathrm{r}} 34$ Peters questions to what extend transparency requirements can be legitimately imposed on private, notably economic actor: supra note 3 , at $55 \mathrm{I}$.

${ }_{135}$ See, for instance, art. 4.2 of the European Convention on the Manipulation of Sports Competitions (supra, note I16), establishing that "(e)ach Party, within its jurisdiction, shall encourage sports organisations, competition organisers and sports betting operators to co-operate in the fight against the manipulation of sports competitions and, where appropriate, entrust them to implement the relevant provisions of this Convention".

136 Not only the executives branches of States, but also domestic parliaments are the beneficiaries of transparency rules. The Laeken Declaration, adopted on 15 December 200I, stressed their role by stating that "( $\mathrm{t}$ )he European Union derives its legitimacy from the democratic values it projects, the aims it pursues and the powers and instruments it possesses. However, the European project also derives its legitimacy from democratic, transparent and efficient institutions. The national parliaments also contribute towards the legitimacy of the European project. The declaration on the future of the Union, annexed to the Treaty of Nice, stressed the need to examine their role in European integration". The Laeken Declaration is available at <http://europa.eu/rapid/press-release_DOC-oI-I8_en.htm> accessed 5 October 20I5. On this question see, for instance: A. Cygan, Accountability, Parliamentarism and Transparency in the EU. The Role of National Parliaments (Edward Elgar Publishing, Cheltenham, 2013).

${ }_{137}$ Cfr. Principles i8 ("States shall immediately notify other States of any natural disasters or other emergencies that are likely to produce sudden harmful effects on the environment of those States. Every effort shall be made by the international community to help States so afflicted") and is ("States shall provide prior and timely notification and relevant information to potentially affected States on activities that may have a significant adverse transboundary environmental effect and shall consult with those States at an early stage and in good faith" of Rio Declaration on Environment and Development, adopted in June I99I, text available at < http://www.un.org/documents/ga/confi5I/aconfi5I26-Iannexi.htm> accessed 5 October 2015.

${ }_{13} 8$ Peters, supra note 3 , at 553.

${ }_{139}$ As already noted, "reputational concerns can provide states with an incentive to comply with international legal rules”: A. T. Guzman, How International LawWorks. A Rational Choice Theory (Oxford University Press, Oxford, 2008), at 9. As Francks concludes, States often follow International Law even in the absence of any real concern about sanctions: quoted by M. E. O'Connell, The Power o $\mathcal{O}$ Purpose of International Law. Insights from the Theory $\mathcal{G}$ Practice of Enforcement (Oxford University Press, Oxford, 20II), at 85. 
Regarding, for instance, the guarantee of the right to access to information, it has to be taken into account that international UN treaty regimes, special procedures of the Human Rights Council, and the Universal Periodic Review relied on monitoring mechanisms that, such as self-reporting or blaming and shaming, do not end with the imposition of binding decisions on State parties. Regional human rights systems go further, since final judgments of the regional human rights courts shall be abided by contracting parties. ${ }^{140}$ As a consequence of the assumption by States parties of the obligation of securing to everyone within its jurisdiction the rights defined in the corresponding human rights convention, ${ }^{\mathrm{I} 4 \mathrm{I}}$ judgments of the regional human rights courts shall be executed. Thus, the respondent State has to put an end to the violation, make reparation, and not repeat the violation. Apart from these specific contexts, "(w)hen self-reports, public condemnation and blacklisting of States does not help to bring them into compliance with international law, stiffer enforcement mechanisms are largely lacking". ${ }^{42}$

\section{CONCLUDING REMARKS}

Certain expressions are common in everyday usage, as though their meaning were obvious, despite the conceptual vagueness surrounding them. In my view, transparency, good governance and (the fight against) corruption undoubtedly fall into this category. The three of them have a moral, sociological and political dimension. What I have tried to show in this paper is that they also have an international legal one. And that they have been embedded in International Law instruments as goals or objectives to be pursued in different realms.

Different positive obligations regarding the promotion of transparency and good governance and the fight against corruption are enshrined both in soft law and hard law international instruments. In particular, some of these obligations are contained in binding international treaties or resolutions of International Organizations pertaining to different sectors of International Law. Consequently, they have a hard law nature. The action of International Organizations in fighting corruption, and relevant developments regarding the protection of the right to access to information, International Financial Law, Administrative Global Law, and International Sports Law have been examined here. The comparative examination shows how transparency, good governance and the fight against corruption have been assumed as positive values by different sectors of International Law and have emerged across the legal remedies and procedures described in this paper to become new standards in contemporary International Law. Finally, this article has tried to show the difficulties in summarizing the legal outlines of an internationally imposed obligation of transparency.

Thus, although the concrete content of the obligations imposed on States, International Organizations, or even non-state actors, by those international instruments are context-dependent, I

${ }^{140}$ See art. 46.I of the European Convention of Human Rights, art. 68 of the American Convention on Human Rights, and art. 30 of the Protocol to the African Charter on Human and People's Rights on the Establishment of an African Court on Human and Peoples' Rights.

I4r See art. I of the European Convention of Human Rights, art. I of the American Convention on Human Rights, and art. I of the African Charter on Human and People's Rights.

${ }^{142}$ Peters, supra note 3, at 545. 
think it can be concluded that fighting corruption and promoting good governance and transparency have been proposed as new standards by Public International Law. In general, they are perceived as positive values, and this perception has facilitated their emergence in contemporary International Law, even as global public goods. ${ }^{\mathrm{I} 43}$

This is the case for transparency. Although it is not conceived as an absolute obligation or objective, ${ }^{\mathrm{I} 44}$ transparency has gathered a considerable success in recent times. Notwithstanding this general consensus, transparency has got criticism from some scholar. Thus, Bianchi warns against the "dark side of transparency": information can be easily manipulated and both information overload and disinformation campaigns can generate important damage. ${ }^{145}$ It has been also denounced as a false ideal, the strongest and most pernicious of contemporary myths. Thus, the contemporary and prevailing discourse that supports transparency as a positive value would not take into account that a society that demands absolute transparency is a society that has decided not to trust and wagers for control and surveillance. ${ }^{\mathrm{I} 46}$ This society would reverse the panoptic model designed by Bentham ${ }^{\mathrm{I} 47}$ "placing the people in the lookout and recasting the state as the object of surveillance". ${ }^{148}$

I43 Ibidem, at 542-543.

${ }^{144}$ It could pose dangers "to the quality of deliberations, and countervailing legitimate interests such as security, privacy and business or trade secrets": Ibidem, at $57 \mathrm{I}$.

${ }_{45}$ Bianchi, supra note 4, at Io. Lord agrees: "If the trend toward greater transparency continues, it will transform international politics by reducing uncertainty, helping people know each other better, and decentralizing power-but the implications of those developments are complex. Less uncertainty can both encourage and discourage international conflict, and increase and decrease international cooperation. More information about other peoples and cultures can promote or diminish tolerance and the likelihood of violence between groups. Widely available information about foreign conflicts makes third parties either more or less likely to intervene and to stop deadly violence, depending on what transparency shows. More decentralized power gives the weak more influence over the strong and strengthens advocates of democracy but it also empowers terrorists and gives authoritarian governments new instruments of power. Transparency has a dark side": Lord, supra note 48 , at II5.

${ }_{146}$ B.-C. Han, La Sociedad de la transparencia (Herder, Barcelona, 2013). For Hartam, "(t)he utopianism of our society of communication commends transparency: a principle that wishes to have the truth rise to the surface like cream, and so to abolish the esoteric in human contact and communication. But the laudable effort to achieve better oversight of governmental and large business operations is not easily transferred to the private sphere. The assumption that transparency is also desirable in that sphere raises concerns about the invasion of technological mind-snatchers, the subjection of aesthetic constructs to doctrinaire criteria, and the elimination of indeterminate, experimental, or transitional spaces.": G. H. Hartman, 'A Note on Plain Speech and Transparency', i4 Law and Literature (2002), 25-30, at 28.

${ }^{147}$ Jeremy's Bentham's Panopticon made its subjects permanently transparent to authority.

${ }_{148}$ M. Fenster, 'Seeing the State: Transparency as Metaphor' 62 Administrative Law Review (2010) 617-673, at 670. 